\title{
James Tate Goodrich MD/PhD: a renaissance man for all seasons April 16, 1946-March 30, 2020
}

\author{
Michel Kliot ${ }^{1} \cdot$ Dale M. Swift ${ }^{2}$
}

Received: 10 April 2020 / Accepted: 13 April 2020 / Published online: 29 April 2020

(C) Springer-Verlag GmbH Austria, part of Springer Nature 2020

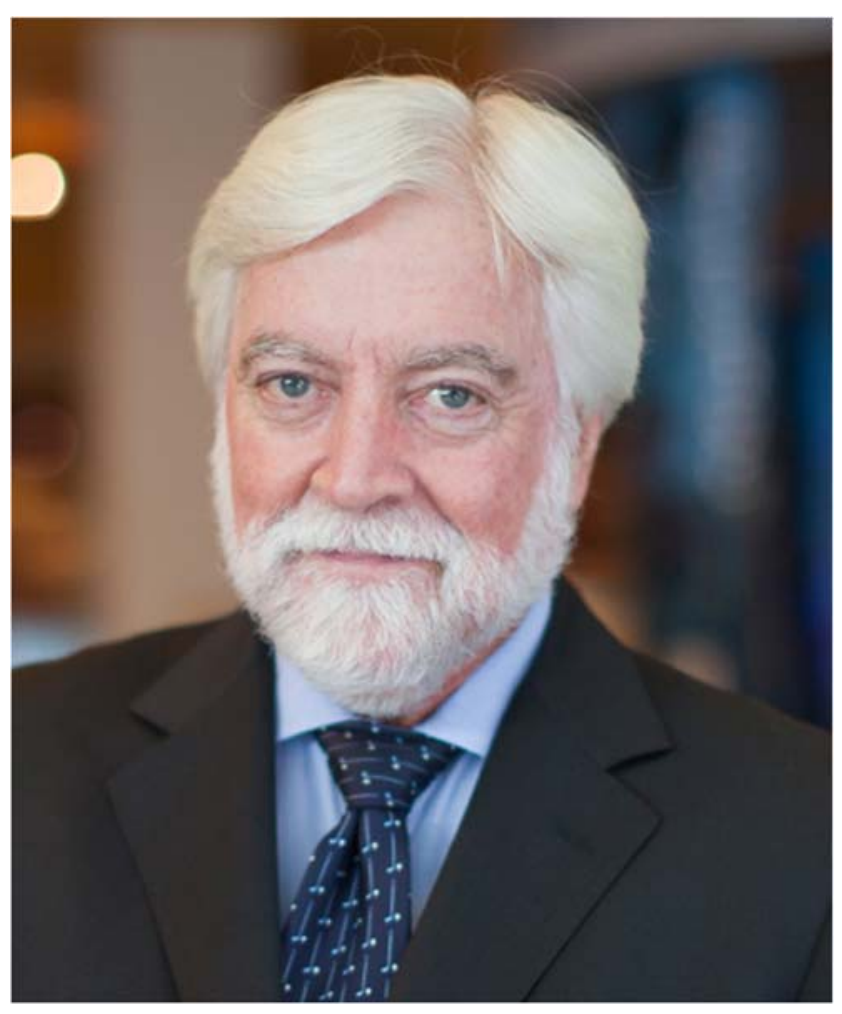

Neurosurgery lost one of its brightest stars on March 30, 2020. To say that James Tate Goodrich was unique and gifted is an understatement. He was extremely talented in so many areas yet so humble and self-effacing. This tribute cannot do justice

Michel Kliot

mkliot@stanford.edu

1 Department of Neurosurgery, Stanford University, Stanford, CA, USA

2 Division of Pediatric Neurosurgery, UT Southwest, Dallas, TX, USA to such a full, productive, creative, and extraordinary life spanning both the arts and sciences.

James Tate Goodrich, known as "Jim" or "JT" to his many friends, was born in Portland, OR, on April 16, 1946. He was raised by a Catholic father, Richard, who worked in advertising, and his Christian Scientist mother, Gail (Josselyn) Goodrich, who was an artist and designer. He received a Jesuit education but admits to barely graduating from high school with a dismal GPA. He then escaped to the California coast where he lived near the beach and spent his time painting houses and surfing. To avoid going to Vietnam, he signed up for the Marine reserves but was sent into combat anyway. During the Tet Offensive, he saw a Vietnamese surgeon in a medical tent opening up a soldier's head. "Cool," he thought. "I want to do that."

Upon return to the USA, Jim married Judy Loudin, the love of his life who gave him the confidence and support to pursue his dreams. He attended Orange Coast community college and parlayed the first good grades of his life into admission to the University of California, Irvine, where he graduated cum laude in 1974. He went on to medical school and graduate studies at Columbia University receiving both an M.D. and Ph.D. Surgery internship and neurosurgery residency training were completed at Presbyterian Hospital in New York City and the New York Neurological Institute. According to Jim, he did not set out to specialize in pediatrics, but when he finished his residency in 1986, there were two neurosurgery positions open: pediatric neurosurgery at Montefiore and adult neurosurgery in Oklahoma. His wife, Judy, a dental hygienist who had already moved across the country so Goodrich could attend medical school, was not about to move to Oklahoma; thus, the choice was clear. After joining the staff at the Albert Einstein College of Medicine, Jim rose to become Professor in the Department of Neurosurgery and served as the Chief of Pediatric Neurosurgery at Montefiore Medical Center, Bronx, NY.

I (MK) first met Jim when he was Chief Resident at the Neurological Institute and I was his very green junior resident. What struck me immediately was his calm and reassuring aura present even in the most tumultuous of situations. He spoke in a 
baritone voice with an economy of words full of meaning, revealing a sharp wit, with an ever-present gleam in his eyes. He struck me as looking like the handsomely attired Captain of a seaworthy vessel. In fact, a patient of mine who was a famous nautical artist actually placed Jim into one of his paintings. Jim had a Charlie Chaplin-like ability to see things deeply and clearly from the outside in and a Mona Lisa-like gaze that followed you everywhere. He was ageless and timeless; recent photographs of Jim, and for that matter Judy, do not differ much from those taken 30 years ago.

Jim was a superb neurosurgeon both clinically and technically. As a pediatric neurosurgeon, he cared for families as well as patients. I (DMS) personally inherited a number of patients and their families whom Jim had cared for before they moved from New York. They revered their Dr. Goodrich and, missing him, would often ask, "Is this OK with Dr. Goodrich?"

Jim's contribution to pediatric neurosurgery extended beyond patient care. He had particular interest in the treatment of craniofacial abnormalities which led him to become the world's expert on the esoteric topic of craniopagus twins. Jim realized early on that most of these incredibly complex surgeries required a large team and needed to be done in stages to give the brain a chance to adapt to vascular changes. His first separation surgery was on conjoined twins from the Philippines and he subsequently participated in more craniopagus procedures than anyone before and probably ever. A CNN documentary - "Separating the Twins" won the Academy of Television 2018 Emmy Award for Outstanding Science, Medical, and Environmental Reporting.

Perhaps more than anything Professor Goodrich was a teacher. He provided an exemplary model for more than three decades of residents. His participation in the teaching forums sponsored by the International Pediatric Neurosurgery Societies educated and enlightened scores of young neurosurgeons over the world. His lectures were informative and entertaining, truthful, irreverent, and never self-aggrandizing. He was always available to trainees after a practical course and many of them received their most interesting lessons just as the pub was closing.
Before there was advertising's "world's most interesting man," there was James Goodrich. His fund of knowledge appeared unlimited. You could talk to Jim about anything and he always seemed to comprehend the topic far more than anyone in the room. His knowledge of wines rivaled that of a sommelier in a three star Michelin restaurant. In fact he had a wine cellar in his beautiful home overlooking the Hudson River in Nyack, NY, with over 6000 bottles. Amazingly, he knew where every bottle was stored. In one area was a collection of personal possessions that were from one of his military buddies who was not so fortunate to have survived.

James Tait's appreciation of the past was abundantly evident in his love of medical history and antiquities. I was privileged to see his library which was out of a Jules Verne novel and Spielberg film. It had a cathedral-like feel with two levels of books numbering in the hundreds. His collection included two Vesalius atlases and many other highly valued books with many in the field of neurology and neurosurgery. In addition to collecting, Professor Goodrich authored scores of articles on the history, and indeed the prehistory, of neurosurgery. Among Jim's collections was Cushing's desk as well as a casting of his hand along with many other valuable items. Most surprising of all were several shrunken heads. Against the wall were close to one hundred didgeridoos of all colors and lengths, which of course Jim could play. Jim had a way of integrating his hobbies into his professional life and he had a successful rare medical book business. Every year he would send out a beautiful catalog.

James Goodrich will be remembered as one of the masters of craniofacial surgery and in particular the separation of craniopagus twin where his record of success is unrivaled. He was a unique individual with many interests and capabilities: a true renaissance man for all seasons. He is survived by Judy, his wife, and his three sisters, Kristine Goodrich, Jan Rentenaar, and Carol Mentecucco. We extend our deepest condolences to his family, friends, and colleagues around the world. 